\title{
Intellectuals And The State : The Finnish University Intelligentsia And The German Idealist Tradition
}

Kortti, Jukka

2014-08

Kortti , J 2014 , ' Intellectuals And The State : The Finnish University Intelligentsia And The

German Idealist Tradition ' , Modern Intellectual History , vol. 11 , no. 2 , pp. 359-384 . https://doi.org/10.1017/S1479

http://hdl.handle.net/10138/227988

https://doi.org/10.1017/S1479244314000055

cc_by_nc

acceptedVersion

Downloaded from Helda, University of Helsinki institutional repository.

This is an electronic reprint of the original article.

This reprint may differ from the original in pagination and typographic detail.

Please cite the original version. 
INTELLECTUALS AND THE STATE:

FINNISH UNIVERSITY INTELLIGENTSIA AND ITS GERMAN IDEALISM TRADITION

Jukka Kortti, Adjunct Professor (Docent)

University of Helsinki,

Department of Political and Economic Studies, Section of Social Science History

jukka.kortti@helsinki.fi

Article (Accepted version)

Post-print (ie final draft post-refereeing)

Original citation: JUKKA KORTTI (2014). INTELLECTUALS AND THE STATE:

THE FINNISH UNIVERSITY INTELLIGENTSIA AND THE GERMAN

IDEALIST TRADITION Modern Intellectual History, 11, pp 359-384

doi:10.1017/S1479244314000055 


\section{Abstract \\ INTELLECTUALS AND THE STATE: \\ FINNISH UNIVERSITY INTELLIGENTSIA AND ITS GERMAN IDEALISM TRADITION}

The article examines the making of the Finnish intelligentsia and its relation to the state and the nation. The problem is analysed primarily from the perspective of student activism in the twentieth century. The development is viewed in the context of nationalism, (cultural) modernism, and radicalism in the development of the public sphere. The main source consists of the research findings of the student magazine Ylioppilaslehti (Student Magazine), which is not just "any student paper," but a Finnish institution that has seen most of Finland's cultural and political elite pass through its editorial staff in the twentieth century. The article demonstrates the importance of German idealism, as theorised by the Finnish statesman and philosopher J.W. Snellman, and its vital role in the activities of the Finnish university intelligentsia well into the $21^{\text {st }}$ century. 
INTELLECTUALS AND THE STATE:

FINNISH UNIVERSITY INTELLIGENTSIA AND ITS GERMAN IDEALISM

TRADITION

INTRODUCTION

In 2013, there has been quite a fuss around Finnish philosopher Pekka Himanen in the Finnish public sphere. Himanen is internationally known as the researcher of the information age - together with Spanish sociologist Manuel Castells, for instance. The discussion started when the investigative web journal Long Play published an $\operatorname{article}^{1}$ about Himanen in February 2012. The article questioned Himanen's academic competence but also revealed the close relationship between Himanen and Prime Minister of Finland Jyrki Katainen. Himanen had received an assignment to make a future account for Finland - a model for sustainable growth. It looked as if the Prime Minister had inappropriately used his influence on the process in which three major Finnish governmental research funding institutions had been forced to support Himanen's proposal without soliciting the submission of alternate proposals, as is the customary practice. Himanen was called, among other things, the "Prime Ministers's best friend".

This assignment was not the first one awarded to Himanen. The previous government of Finland, where Katainen was Minister of Finance, had ordered a future account of how the Finnish culture would blossom in the 2010s. The analysis, published as a book in March 2010, was titled

\footnotetext{
${ }^{1}$ See http://longplay.fi/himasen_etiikka/
} 
Kukoistuksen käsikirjoitus ${ }^{2}$ (The Script for Blossoming). The book received reviews ranging from modest commentaries to brickbats. The objects of criticism were several, but one theme, mentioned especially by other philosophers, concerned Himanen's role as a "state philosopher": you cannot be a "free philosopher" and write blue books for the state at the same time!

However, there were clear precedents for Himanen's assignment in contemporary Finnish history. In 1993, Prime Minister Esko Aho asked philosopher and later Chancellor of the University of Helsinki Ilkka Niiniluototo to assemble a working group tasked with providing an accounting of the mental state and the future of Finland. The results were published as a book ${ }^{3}$ as well. One of the few independent or "free" Finnish intellectuals, writer Erno Paasilinna, criticised the working group in 1996, remarking that intelligentsia should be always in opposition, and they could not be whistled to like a dog at some Prime Minister's beck and call. ${ }^{4}$

The connection between the intelligentsia and the state can also be found in other countries in recent years. One of the most famous examples is British sociologist Anthony Giddens being an adviser to the former British Prime Minister Tony Blair. His “third way” political approach was Blair's guiding political idea. However, strong ties between the State and intellectuals have long historical roots, especially in Finland. In general, the intellectuals in Nordic countries have never really become an alienated stratum with an independent tradition vis-à-vis the state. Intellectuals in Nordic countries have often been used in the service of society. Hence rather than remaining in the marginal avant-garde, they have been at the centre of society. ${ }^{5}$ This does not fit the preconceptions which assume that to call a person an intellectual is to suggest that in some basic way he or she

\footnotetext{
${ }^{2}$ Pekka Himanen, Kukoistuksen käsikirjoitus (Helsinki, 2010).

${ }^{3}$ Ilkka Niiniluoto and Paavo Löpponen, eds., Suomen henkinen tila ja tulevaisuus (Porvoo, 1993).

${ }^{4}$ Pertti Karkama and \& Hanne Koivisto (1997), "Sivistyneistö ja älymystö Suomessa" In P. Karkama and A. Koivisto, eds., Älymystön jäljillä. Kirjoituksia suomalaisesta sivistyneistöstä ja älymystöstä. Tietolipas 151, (Helsinki, 1997$), 9$.

${ }^{5}$ Ron Eyerman, "Intellectuals and the State: A Framework for Analysis, with Special Reference to the United States and Sweden", in N. Kauppi and P. Sulkunen, eds., Vanguard of Modernity. Society, Intellectuals, and the University, Publications of the research unit for contemporary culture 32, (University of Jyväskylä, 1992), 73.
} 
stands against or apart from the contemporary dominant culture. Intellectuals have been in the habit of questioning and challenging values and assumptions that were taken for granted in their societies. ${ }^{6}$

When intellectual historian Ron Eyerman refers to the "intelligentsia," he means the historically specific stratum that "forms a social category which takes form in varying social and cultural contexts in relation to norms and traditions reaching back to pre-industrial society. Intellectuals are first of all that social category which performs the task of making conscious and visible the fundamental notions of a society." The concept of "intelligentsia" was formed in Eastern Europe (Russia and Poland) in the early nineteenth century, and the state was its ally. But since then the concept has had many variations. ${ }^{7}$

In Finland, the university intellectuals and the state have lived in symbiosis in an extraordinary way. This relation is illustrated more clearly than perhaps in any other country on Helsinki Senate Square: the university and the senate are situated opposite each other in similar buildings, the only difference being the university's Ionic colonnade as Hellas and the Senate's Corinthian colonnade as Rome. Another manifesting symbol of this alliance in the University of Helsinki can be found inside the University building. On the wall of the Great Hall there is a painting depicting the inaugural procession of the University in July 1640 in Turku, where the University was located until 1828. The central figure in the picture is not a university man, but a representative of the government - Count Per Brahe, the true founder of the University, who at that time was Governor

\footnotetext{
${ }^{6}$ See e.g. Lewis S. Feuer, "What is an Intellectual?" in Aleksander Gella, ed., The Intelligentsia and the Intellectuals: Theory, Method and Case Study (Los Angeles, CA, 1976), 48; Seyrmor Martin Lipset and Asoker Basu , "The Roles of the Intellectual and Political Roles", in Aleksander Gella, ed., The Intelligentsia and the Intellectuas: Theory, Method and Case Study (Los Angeles, CA, 1976), 112.

${ }^{7}$ See e.g. Ron Eyerman, Between Culture and Politics. Intellectuals in Modern Society, (Cambridge, 2004), 6 (citation), $16-31$.
} 
General of Finland. Power and learning have traditionally been closely allied in Finland. University professors dominated not only the intellectual but also the political field in Finland until the Second World War. ${ }^{8}$

Although the link between elites and the stratum of intelligentsia is not automatic, cultural, political, bureaucratic, and other elites can be conceived as composing part of a whole called the intelligentsia. ${ }^{9}$ In this article, I discuss the role of a Finnish intellectual from the viewpoint of student and other intellectual activism in the twentieth century. I look at intellectuals both from the phenomenological point of view, i.e. the self-understanding and perceptions of the individual, and from the structural point of view, which takes as its starting point an objective, observable position in the social structure. ${ }^{10}$ "Objective," of course, means meeting the standards of a given historical society. In any case, the emphasis is on the latter approach. ${ }^{11}$

I am particularly interested in the making of the Finnish intelligentsia and its relation to the state and the nation. I look at the development in the context of nationalism, (cultural) modernism, and radicalism in the development of the public sphere. The aim is not, however, to provide a full "total historian" account of Finnish intellectual history, but to extract a few examples of the long durée of the relationship between the Finnish university intellectuals and the State through historical turmoil. The main source consists of the research findings ${ }^{12}$ of the student magazine Ylioppilaslehti (Student

\footnotetext{
${ }^{8}$ Matti Klinge (1992) "Intellectual Tradition in Finland”, in N. Kauppi and P. Sulkunen, eds., Vanguard of Modernity. Society, Intellectuals, and the University, Publications of the research unit for contemporary culture 32, (University of Jyväskylä, 1992), 41; Anto Leikola, "In Sercvice of the Truth or of the Emperor. Some reflections on the loyalties of the University of Finland", in M. Norrback and K. Ranki, ed., University and Nation: The University and the Making of the Nation in Northern Europe in the $18^{\text {th }}$ and $20^{\text {th }}$ Centuries, Studia Historica (Helsinki, 1996), 125.

${ }^{9}$ Peter C. Ludtz, "From methdological Problems in Comparative Studies of the Intelligentsia", in Aleksande Gella, ed., The Intelligentsia and the Intellectuas: Theory, Method and Case Study (Los Angeles, CA, 1976), 37.

${ }^{10}$ Ron Eyerman and Lennart G. Svensson and Thomas Söderqvist ,"Introduction" in R. Eyerman and L. G. Svensson and T. Söderqvist Intellectuas, eds., Universities and the State in Western Societies (London, 1987), 3.

${ }^{11}$ I have analysed the particular ways of thinking and acting of the Finnish student leaders more in other contexts. See Jukka Kortti, "Generations and Media History" In L. Fortunati and F. Colombo, eds., Broadband Society and Generational Changes, Series: Participation in Broadband Society - Volume 5, (Frankfurt am Main, Berlin, Bern, Bruxelles, New York, Oxford, Wien, 2011), 69-93.

12 Jukka Kortti, Ylioppilaslehden vuosisata, (Helsinki, 2013).
} 
Magazine), which is not just "any student paper," but a Finnish institution that has seen most of Finland's cultural and political elite pass through its editorial staff in the 20th century.

\section{THE SNELLMANIAN PATRIMONY}

The role of intellectuals in society is dependent on the possibilities and the constraints provided by both tradition and context. The social conditions and political beliefs, as well as relations to wider social movements, fashion intellectuals in different cultures and in different times. ${ }^{13}$ In Finland, the tradition of the intelligentsia is highly influenced by one person, J. V. Snellman (1806-1881). In his early career, the philosopher and statesman was deeply influenced by the main philosophical trend of the 1840s, Hegelianism. Snellman laid the intellectual foundations of the Finnish state in his Lärän om Staten (The Idea of the State) in 1842, in which he promoted the idea of the authority of the state at the expense of the more liberal civil society.

Snellman absorbed the Hegelian ideas of the superiority of the state and patriotism through his teacher J. J. Tengström in the 1830s. Tengström went even further than his master Hegel by stating that selfish individuality, even produced by Weltgeist (the spirit) according to Hegelian thinking, is bad for the status quo and tradition. Tengström emphasised the role of civil servants who had to be rational, ethical (Sittlichkeit), and devote themselves to the citizens and the fatherland. The lectures of Tengström had far-reaching consequences for Snellman and other Finnish followers of German idealism, because the construction provided the possibility for the Finnish intelligentsia to identify with the state. Following the ideas of Tensgström, Snellman emphasised national cultural identity and linguistic nationalism as the essence of a sovereign state. In that sense, he followed the ideas of J.G. von Herder rather than Hegel, especially when placing emphasis on language. For Snellman,

\footnotetext{
${ }^{13}$ Eyerman, Between Culture and Politics, 3.
} 
language - especially its vocabulary — was not just an external medium for people to communicate their thoughts to each other, but something to express the common experience of a nation and a specific way of understanding the world. As a one example of his view, he claimed that that the Grand Duchy of Finland, which was a part of the Russian Empire from 1809 to 1918, was on a higher developmental level than the independent state of Switzerland, where the national spirit seemed to be sleeping due to the multiethnic, multilingual character of that country. We can also find the influences of the language philosopher Wilhelm von Humboldt in Snellman's thinking. ${ }^{14}$

Bildung (education) was also an essential concept in Snellman's thinking and action. His conception of the university was based on it: the university was both for advancing science and for training in moral and ethical living. Primarily, the aim of a university education was not just for providing degrees, offices, or salary. In this sense, the views of Snellman have been seen in the classical Humboldtian or neo-humanistic ${ }^{15}$ frame of reference, in which the freedom of research, teaching and studying is a central, intrinsic value. But this academic freedom of the university, especially after Snellman finally became a professor in 1856, developed into an implement for organizing the functions of the state. The schools should educate people for the civil society, and the university, again, for the service of the state. But the university cannot be like a school. For Snellman, the essence of academic studies was the pursuit of knowledge and ethical life that arises from recognition of the rights of self-consciousness. This is Snellman's justification for the principle of academic freedom. As a Hegelian, he believed, more than his master actually, that the ethical life of the state is mediated by subjectivity. In Snellman's thinking, a citizen's loyalty should be, in the

\footnotetext{
${ }^{14}$ Marja Jalava, J. V. Snellman. Mies ja suurmies. (Helsinki, 2003), 40-4, 117-8.

${ }^{15}$ Actually the Humboldtian ideas were part of a wider historical and cultural movement in the context of the sentimental turn of the late Enlightenment followed by neo-humanism and romanticism as well as the increasing power of the absolutist state and the growths of a bureaucratic intelligentsia. See e.g. David Sorkin, "Wilhelm Von Humboldt: The Theory and Practice of Self-Formation (Bildung), 1791-1810" Journal of the History of Ideas, 44, 1 (1983), 55-73.
} 
first place, loyalty to the nation, in the framework of which the individual personality could achieve fulfilment. ${ }^{16}$

As the scholars of nationalism have stated, nationalism can be seen as "civic religion" for a young, “ahistorical nation." It has also been a suitable ideology for the elite to persuade common people to identify with a modern state. ${ }^{17}$ In this tradition, Finland belongs to Western rather than Eastern Europe, where nationalism has been a liberating force for an oppressed people. ${ }^{18}$

\section{EDUCATING STATE BUREUCRATS FOR THE GRAND DUCHY OF FINLAND}

The Finnish view, however, was dissimilar to the former mother country of Sweden. ${ }^{19}$ The Swedes acknowledged, in the spirit of moderate liberalism, that people have many rightful orientations, which are not commensurable, but compete with each other. However, in the Grand Duchy of Finland, the circumstances favoured consensus. The Finnish intelligentsia had to concentrate on the development of the state in contrast to old European nation-states, in which the mental resources could be directed to multiple orientations. Especially in its difficult political situation as a part of absolutistic Russia, the Finnish university system could not fully provide a free forum for intellectual activity.

Yet Finland was allowed to retain most of the important institutions under Russian rule. First of all, local government - the Imperial Senate of Finland since 1816 - remained much as it had been under

\footnotetext{
${ }^{16}$ Jalava, J. V. Snellman, 54-61; Juha Manninen, “Academic Freedom” in Semi-Ramistic Studies: Essays in Honour of Raimo Tuomela, Report from the Department of Philosophy, University of Helsinki, 5/1980, (Helsinki 1980), 22-31; Leikola, "In Service of the Truth or of the Emperor", 128.

${ }^{17}$ Ernest Gellner, Thought and Change (London, 1964), 164-72; Eric Hobsbawm, "Some Reflections on Nationalism", in T.J. Nossiter \& A.H. Hanson \& Stein Rokkan (eds.), Imagination and Precision in the Social Sciences (London, 1972, 395-401.

${ }^{18}$ See Risto Alapuro, Suomen älymystö Venäjän varjossa (Helsinki, 1997), 17-22.

${ }^{19}$ Finland was a part of the kingdom of Sweden from the Middle Ages until 1809 when - after the Napoleonic Wars - it became an autonomous Grand Duchy in the Russian Empire.
} 
Sweden, although its powers were rather circumscribed. Another important institution, the University, was reformed and named after the $\operatorname{Tsar}^{20}$ as Imperial Alexander University after it moved from Turku to Helsinki in 1828. The Senate effectively took education under its wing, and the University became first and foremost an institution to educate bureaucrats to serve the State. The Finnish settlement was not unique in Russian history ${ }^{21}$, but Finland maintained its special status and was able to develop a political and cultural autonomy during the nineteenth century which resulted in full independence after the Russian revolution.

Alexander I, who declared that Finland should take its place "in the rank of nations, governed by its own laws" including religion and customs, was considered to be a liberal in the climate of contemporary Europe. His successor Nicholas I was more of a paternal autocrat than a spiritual and intellectual Tsar as was his brother. He put an end to several areas of local autonomy including Poland in 1830, but Finland was able keep its autonomy partly due to Finnish loyalty. However, his successor Alexander II, 'The Good Tsar', was a real reformer, and Finland became sort of a laboratory to test his reforming ideas. Actually, Russia was economically backward compared to Finland. When the Emperor granted relatively wide freedom for its "overdeveloped" province 22 , most of the mutual benefit favoured Finland. Especially for the growth of the forest industry - the footing for the Finnish economy until the late twentieth century before Nokia and other high tech clusters - the big Russian markets were extremely important. Alexander II established Finland's own currency and liberated business, but also encouraged Finns to elevate Finnish to a national language.

\footnotetext{
${ }^{20}$ Finnish Diet recognized Tsar Alexander I as Grand Duke.

${ }^{21}$ The Baltic provinces also retained some of their former institutions, and in 1815 the Congress of Vienna agreed to the formation of a Kingdom of Poland as an internal autonomy of Russian sovereignty. But later in the nineteenth century Poland was treated as an occupied territory and the Baltic Provinces were incorporated into the Russian system of government.

${ }^{22}$ Only Croatia, Bohemia and the Polish parts of Russia could be compared to Finland as relatively overdeveloped countries in the contemporary Russian Empire. (Tom Nairn, The Break-Up of Britain (London, 1977), 120.
} 
However, Russians allowed Finnish bureaucrats to work relatively independently only insofar as Finland offered a model for efficiency and good administration for the rest of Russia. When situations changed in the mid-nineteenth century along with the rising nationalism in Europe as well as in the Russian provinces, the new generation of Finnish elite such as Snellman started to forge Finnish statehood in a different manner. However, it did not mean revolution, as in Poland, but new manoeuvres behind the scenes to win the emperor's approval. For instance, in the European Revolutions of 1848 , which arose from a wide variety of causes linked to modernisation (ideologies, technological change, and urbanisation), the students went to barricades in Central Europe, but the Finnish students spent their spring day celebration by hurrahing for the Emperor. Historically, Finns have been relatively moderate in protesting. In addition, demonstrations and protest marches have characteristically been orderly and organized ${ }^{23}$. Overall, it is somewhat unusual that activists of a nationalistic movement were actually co-opted into the bureaucracy.

\section{MODERN INTELLECTUALS AND THE STATE}

On the other hand, Finland was experiencing a slow modernisation process during almost the entire nineteenth century. When modernisation is rapid, the arenas of society and culture diverge from each other and lay the groundwork for oppositional intelligentsia. In fact, the whole concept of the "intellectual" is a child of Enlightenment and reaction, supporting or opposing modernism. ${ }^{24}$

Overall, the modern concept of intellectuals entered European culture in connection with the socalled Dreyfus affair at the turn of the $20^{\text {th }}$ century. ${ }^{25}$ To be an intellectual meant autonomy-

\footnotetext{
${ }^{23}$ See Alapuro, Suomen älymystö Venäjän varjossa, 28-54.

${ }^{24}$ Jalava, J. V. Snellman, 47-48; Eyerman, Between Culture and Politics, 27; Hanne Koivisto, "Ihmisryhmä, jossa moraali ja äly yhtyvät: intellektuellin käsitteestä”, in L. Rossi \& H. Koivisto, eds., Monta tietä menneisyyteen, (Turun yliopisto, 1995).

${ }^{25}$ The Dreyfus affair was a political scandal that divided France in the 1890s and the early 1900s. Captain Alfred Dreyfus, a young French artillery officer of Alsatian Jewish descent, had been falsely declared guilty of leaking security
} 
distance from the corridors of power. But by then the intellectuals were already divided into two camps. In addition to the liberals in defence of Dreyfus, there were also conservative defendants of national values, the army, and established social hierarchy. In universities particularly, this division was defined as the degree to which individuals were bound to legitimate social structures within and outside university. Some, mostly representing humanities and modernism, were more autonomous and likely to choose the universalist liberal camp, while more traditional sciences, dependent more on the state, went to the conservative camp. All in all, the Dreyfuss Affair helped to solidify intellectuals as intelligentsia. Now they could function as a distinct group in society with a moral mission against the established authority. ${ }^{26}$

Although the French case was unique, explained by the tradition and the structure of the Parisian elite, the same kind of movement can be found in other parts of Europe as well. In Finland, the modernisation process forged ahead in the late nineteenth century. One of its features was that the traditional social order of the four estates and the ecclesiastic regulation system started to shatter. The traditional customs and mores as well as the attributes of social status were called into question. If we approach this development from the point of view of subjective modernity and consider not only linear goal-orientation, but also multidimensional fragmentation, it meant changes in the identity of an individual. The selfhood and identity became relatively loose, and "self" was now seen as a reflexive project. But still, this was done in the tradition of German Idealism. As the Finnish intellectual historian Marja Jalava, who has studied this change through the Finnish liberal moral philosopher Rolf Lagerborg, has put it, the main question and problem concerned the relation between Sittlichkeit (morality) and Sinnlichkeit (sensuality) and their "reconciliation"

\footnotetext{
information to Germans. When Emile Zola, man of letters, reproached the government for denying Dreyfus his right to justice, several public figures joined to support Zola. The term intellectual appeared a couple of days later in a newspaper article referring to Zola and his associates. 'Intellectuals' not only became a term in popular use, but has a sarcastic connotation at first. (see e.g. Eyerman, Between Culture and Politics, 53-67.)

${ }^{26}$ Pekka Sulkunen, "The formation of intellectuals as social group" in N. Kauppi and P. Sulkunen, eds., Vanguard of Modernity. Society, Intellectuals, and the University, Publications of the research unit for contemporary culture 32, (University of Jyväskylä, 1992), 9; Eyerman, Between Culture and Politics, 38.
} 
(Versöhung). ${ }^{27}$ Lagerborg was distinctively a Swedish-speaking ${ }^{28}$ university intellectual - an aristocrat, who was not only liberal but also internationally oriented. But internationality and liberalism attracted the Finnish-speaking intelligentsia as well.

The period aroused liberalism, but also cultural criticism and the first Finnish modernists in literature. Especially after the nationalistic Fennoman movement ${ }^{29}$ divided in two, the liberal writers of this group of "Young Finns" wanted to "open windows" to Europe. For the first time, the Finnish intelligentsia was centred in the circles of artists, men of letters, and journalists instead of students or politicians. Especially men of letters (authors, poets, writers, journalists) such as Juhani Aho and Eino Leino, who later became the Great Men of Finnish literature, resembled the archetype of a French intellectual. They were academic, travelling, language-skilled individuals_ — virtual renaissance figures, who knew art circles and were interested in different kinds of social, political and cultural topics. The resemblance to France was not accidental, however, since Juhani Aho even wrote articles about the Dreyfus affair, for instance. ${ }^{30}$

Those Finnish international liberals ran into trouble after Nicholas II came into power. He initiated processes that have been called "the Russification of Finland." Especially after General Nikolay Bobrikov became governor-general of Finland, he started a reform aiming to control Russian's western borderland. This meant the strengthening of his own powers, the integration of the armed forces, the abolition of separate customs and monetary systems, and the introduction of Russian into

\footnotetext{
${ }^{27}$ Marja Jalava, Minä ja maailmanhenki. Moderni subjekti kristillis-idealistisessa kansallisajattelussa ja Rolf Lagerborgin kulttuuriradikalismissa n. 1800-1914. Bibliotheca Historica 98, (Helsinki, 2005), 463 (English summary). ${ }^{28}$ The Swedish-speakers started to move to the west coast of Finland in the Middle Ages. Finland became part of the Kingdom of Sweden in the twelfth century. The original mother-tongue of people living in Finland was Finnish except that on the coast there were Swedish-speakers. However, Swedish became the language of the administration and a great many inhabitants of Finland adopted Swedish as their cultural language, and the upper classes also spoke Swedish at home. After Finland became the Grand Duchy of the Russian Empire in 1809, Swedish remained the official language of the country.

${ }^{29}$ The Fennomans were the most important political movement in the Grand Duchy of Finland in the 19th century. The movement pushed to raise the Finnish language and Finnic culture - distance from Swedish or Scandinavian culture from its peasant-status to the position of a national language and national culture.

${ }^{30}$ Koivisto, "Ihmisryhmä, jossa moraali ja äly yhtyvät", 120-1.
} 
the Senate, civil service, and schools. This policy, established in 1899, and often referred to as the “February Manifesto," eventually became known (in Finnish contemporary and subsequent literature) as the beginning of the first "icy times" and "oppression" (1899-1905). Borbikov was assassinated by Eugen Schauman, a nationalist and nobleman, in 1904. Later there was another Russification period (1908-1917) which lasted until the Russian revolution.

The Young Finns, who separated from the more conservative Finnish Party, strongly opposed Russification on a constitutional basis. The roots of the movement (political party 1905-1918) were in the art circles of the late nineteenth century. Besides Aho and Leino, there were other major cultural figures of the "Golden Age of Finnish Art" such as authors Minna Canth and Ilmari Kianto, painters Akseli Gallen-Kallela and Pekka Halonen, and the composer Jean Sibelius. From these circles was established the newspaper Päivälehti. One of the founders and later the editor-in-chief and the owner of the paper, Eljas Erkko, who was also the founder and leader of the Young Finns Party, was exiled by Bobrikov and spent the years 1903-1905 in the United States and Cuba. Meanwhile Päivälehti was disbanded after it wrote positively about Schauman's assassination but started again as Helsingin Sanomat ${ }^{31}$ in the same year. Later in independent Finland, Erkko worked as a Minister for two Finnish governments. Of the other Young Finns politicians, P.E. Svindhuvud, the third President of Finland ${ }^{32}$ (1931-37), was exiled to Siberia during the First World War because he refused to obey the rules requiring the replacement of Finnish officials with Russians.

Hence if we look at the relations of certain factions of Finnish intellectuals to mother Russia in the late nineteenth century and the early twentieth century, the loyalty to the superior State was broken. Compliance politics was questioned along with the wider unrest in the Russian Empire and world politics. This development led to the declaration of independence (1917) and the Finnish Civil War

\footnotetext{
${ }^{31}$ Nowadays, Helsingin Sanomat is the biggest newspaper in the Nordic countries.

${ }^{32}$ The movement provided a background for two other later Presidents of Finland, K.J. Ståhlberg (1919-25) and Risto Ryti (1940-44) as well.
} 
(1918). ${ }^{33}$ The Finnish Civil War had a crucial influence on every intellectual activity, especially during the interwar period. For the major faction of young intellectuals in the 1920s and 1930s, the Civil War meant a "formative experience." 34

\section{ERA OF STUDENT NATIONALISM}

One of the forums for these Finnish-speaking liberals was the magazine Nuori Suomi (Young Finland) published between 1905 and 1907. It was a sort of predecessor for Ylioppilaslehti, which was established in 1913. During its first years, Ylioppilaslehti was mainly a "professional magazine for students" and it reflected the general non-political sentiments of the student world. However, the situation changed in the 1920s. The activities of the university students concentrated specifically on the Academic Karelian Society (AKS). The first institution, which the AKS took over within student circles in 1923, was Ylioppilaslehti. The $\mathrm{AKS}^{35}$ was an extreme right-wing student movement founded in the previous year. The organisation was unfavourable to liberalism, pluralism, socialism and communism, stock jobbing, foreigners, urbanity and "snobbery." It had a strong generational hegemony among the students, especially in the 1930s.

\footnotetext{
33 The Finnish Civil War between the revolutionary Red Guards and Civil Guards started on 27/28 January and ended on 15 May 1918. The War can be seen both as a part of the Russian Revolution and the First World War. After Finland won its independence from Russia in 1917, the radical faction of the Social Democrats started a revolution. The Reds were supported by the Russian Soviet Republic, whereas the non-socialist Whites received military assistance from the German Empire. The Whites saw the war first and foremost as the liberation from Russia. The Whites finally won the bloody and bitter war, but the traumatic and controversial shadows of the war have followed the Finnish people from generation to generation.

34 The idea of "formative experience" comes from the German sociologist and generation theorist Karl Mannheim. According to him, the age of seventeen is important for later development, and he states: "The possibility of really questioning and reflecting on things only emerges at the point where personal experimentation with life begins." (Karl Mannheim, "The problem of generations", in P.G. Altbach and R. S. Laufer, eds., The new pilgrims: youth protest in transition (New York, 1972), 115). Most of the young Finnish activists of the interwar period were born around 1900. ${ }^{35}$ The association emerged from the revenge-spirited Karelian idea. The original idea was to get back the Eastern Karelian territory ceded to Soviet Russia in the "Shame Treaty" of Tartu. According to the treaty, Finnish troops were to be withdrawn from two large border parishes of East Karelia, Repola and Porajärvi, which had been occupied by Finnish troops since 1918 - after Finland became independent from Russia in 1917.
} 
Despite the fact that the AKS activists were on the winning Whites' side of the Civil War, the leaders of the movement still wanted to integrate the working population into their ideal society in the 1920s. The situation changed when the movement split and the remaining faction started flirting with fascism in the 1930s. After that, the workers ${ }^{36}$ had no role in the movement. AKS joined with the fascist-minded People's Patriotic Movement (IKL), which was run by the older academic intellectuals. $^{37}$

In any case, the radical nationalism was nothing new among the university students. The core idea of the Fennoman movement, which came into existence from within the Swedish-speaking elite in the early nineteenth century, was to educate the nation, inspire nationalism among educated people and promote the status of the Finnish language. By the 1840s, Snellman had already become the great master of the Fennoman students. ${ }^{38}$

Among the university students, the ethno-linguistic conflict had moved into a stalemate during the first years of the twentieth century. However, the situation changed after Finland won its independence. The topic which troubled the University of Helsinki the most in the 1920s and 1930s, was the language struggle - the issue of "finnicizing" the university. ${ }^{39}$

\footnotetext{
${ }^{36}$ Unlike Sweden, for example, Finland almost completely lacked the cultural left in the inter-war period - mainly because the communist party was illegal in Finland until 1944.

37 See Risto Alapuro, Akateeminen Karjala-Seura. Ylioppilasliike ja kansa 1920- ja 1930-luvulla. Politiikan tutkimuksia 14, (Helsinki, 1973.

${ }^{38}$ In the 1860 s and the 1870 s, their propaganda also led to the establishment of the Swede-Finn national movement, which already included at that time the idea of giving Swedish speakers their own separate national identity. The Finnish national movement gradually evolved into a class movement, reflecting the division of the Diet into four estates: nobility, clergy, burghers and peasants. Finnish speakers had an edge over clergy and peasants. Swedish was first and foremost the language of the upper class. In the 1880s, there was an extreme radical student fraction called K.T.P., which pushed forward with the total hegemony of Finnishness. See e.g. Ilkka Liikanen, Fennomania ja kansa . Joukkojärjestäytymisen läpimurto ja Suomalaisen puolueen synty, (Helsinki, 1995); Ilkka Liikanen. Aira Kemiläinen, Finns in the Shadow of the "Aryans". Race Theories and Racism, Studia Historica 59 (Helsinki, 1998), 107-128. Particularly about the radical nationalism among the Finnish university students in the late nineteenth century, see e.g. Matti Klinge, K.T.P:stä jääkäreihin. Ylioppilaskunnan historia II, 1872-1917, (Helsinki, 1978).

${ }^{39}$ The language struggle was in fact one of the two dominating topics in Ylioppilaslehti in the 1930s, the other one being the relationships with Estonia based on the "kindred spirit" - the idea of one big Finno-Ugric nation. One of its concrete operational forms was to have active Estonian relations. The whole concept of a kindred spirit was in fact created within Ylioppilaslehti. See Jukka Kortti, “Ylioppilaslehti and the University's Language Struggle in the 1920's
} 
The ethno-linguistic conflict was on the whole a significant national issue during the restless childhood years of Finnish democracy. The conflict had great political importance, as it was directly linked to the struggles among political parties, the position of Swedish speakers, and the rise of nationalism and right-wing radicalism. It penetrated Finnish society extensively during the interwar decades: the Swedishness of economic life was regarded as a far-reaching drawback; finnicizing the army officers developed into an important point of controversy and all levels of education had to take positions in this issue.

The great university student demonstration around the statue of J.V. Snellman on November 1928 became one of the crucial mass events in the University's language struggle. As part of the demonstration, a delegation of students delivered a petition about the University's finnicization to the Council of State, signed by ninety per cent of the student population of the University of Helsinki. Ylioppilaslehti published, in connection with the petition, a special issue with, as its cover, the appeal of the petition. The issue was written in a very declamatory style, appealing to history from the very first line: "During those centuries, of which history knows to tell, the Finnish nation has constantly lived under guardianship. ... Each country's greatness can be said to depend, for the most part, on the abilities of its intelligentsia." 40 Besides, Ylioppilaslehti was an essential actor in collecting the signatures of the petition.

The struggle continued during the entire decade of the 1930s. An additional parliamentary session was suggested as a solution in January 1935. In the parliament, the handling of the language act was delayed by filibustering - marathon speeches of nationalists, which were often written by university

and the 1930's" Kasvatus ja aika, 3 (4) 2009, 7-73; Jukka Kortti, "Ylioppilaslehti and Estonia Before World War II" In K. Alenius and A. Honkala \& S. Wunsch, eds., On the Eastern Edge of the Baltic Sea II. Borders and Integration in the History of the Fenno-Baltic Region, Studica Historica Septentrionalia 58, (Rovaniemi, 2009).

${ }^{40}$ Ylioppilaslehti 21/1928, 409. 
students. The additional parliamentary session was not a success and the situation stood still for a few years. A solution was reached only in 1937.

However, in the 1920s, there were opportunities for the AKS to organise among the cultural intelligentsia. For instance, the main task of the group called Tulenkantajat (The Flame Bearers) was to find a way to take Finland from the so-called "back woods" culture to the new, modern European level of literature. One of the main critics of AKS and other radical right-wing groups among the Finnish cultural intelligentsia during the 1930s was Matti Kurjensaari, who can be described as an archetype of the French-type independent and "outsider" intellectual. ${ }^{41}$ The Finnish minor Left intelligentsia of the 1930s, who had to operate mostly underground, heavily criticised AKS. They did not, by the way, consider AKS members to be part of the intelligentsia, although AKS was an academic movement. They wanted to separate the academic educated class from intellectuals, who did not necessarily need any degrees or diplomas to be an intellectual. First of all, an intellectual had to be in the vanguard of progress and outside the power elites. The main virtues of an intellectual were intellectual integrity and the pursuit of truth and justice.

The University's finnicization project was clearly an issue which penetrated the public's consciousness on a nationwide scale. The students' idealism and politicising in Ylioppilaslehti had reached the arenas of the public sphere at the national level even before the Second World War. It was hoped that the paper might regain this role more or less in the same way, and partly with the same people as before. The objectives of the right-wing students were reminiscent of what Jürgen Habermas ${ }^{42}$ calls the public sphere of republican models of democracy. ${ }^{43}$ The republican tradition

\footnotetext{
${ }^{41}$ Koivisto, "Ihmisryhmä, jossa moraali ja äly yhtyvät", 107-8. However, Tulenkantajat was not actually an opposition for the AKS, because some of the intellectuals operated in both movements. Actually, the group disbanded partly due to political conflicts, as some members ended up being strictly on the left while some openly promoted the values of AKS in the 1930s.

42 Jürgen Habermas, "Political Communication in Media Society: Does Democracy Still Enjoy an Epistemic Dimension? The Impact of Normative Theory on Empirical Research", Communication Theory 4 (2006), 411-26.
} 
stresses the political participation of active citizens. It is particularly interested in rational choice or political ethos.

Many of the student activists of the 1920s, such as editor-in-chief of Ylioppilaslehti (1927-1928) Urho Kekkonen, eventually became national politicians in the 1930s. Later, Kekkonen became the 8th president of Finland (1956-82). As a student publication, Ylioppilaslehti evoked a significant response in the Finnish public sphere - a position which continued after the Second World War, but in a different manner.

\section{POST-WAR CULTIVATING OF HIGH CULTURE}

After the Second World War, Ylioppilaslehti had to separate from the right-wing nationalistic tones that had permeated the student activist movement before the war. The solution was to concentrate on high culture. This was also the official state policy - a kind of mental war reparation agenda. Ylioppilaslehti started to follow this idea in an organised way, and it soon became a major arena for Finnish cultural criticism. Many of the most important Finnish authors, writers and critics contributed to Ylioppilaslehti in the 1950s and 1960s, and many of the editors of the paper later ended up in top positions in Finnish cultural institutions.

In the 1930s, underlining Finnish culture also involved rejecting other cultural influences and closing the window to the breaths of the sprouting European modernism of the 1920s. After the Second World War, in the so-called "second republic" of Finland, the political struggle concerned the soul of the nation. In this clash, cultivating with high culture (art, literature, theatre, music,

\footnotetext{
${ }^{43}$ Habermas also wants to make a distinction between this model and his criticised concept of the deliberative democracy model, which was central to the concept of the normative public sphere in his dissertation. In short, the deliberative democracy model is the formation of considered public opinions. It is interested in the epistemic function of discourse and negotiation.
} 
architecture, and also film) played a big role. Despite the juxtapositions, a very literary liberal and independent intelligentsia began to emerge in Finland in the 1950s. People were motivated by "an immense hunger for culture" after the war. Basically, this applied to all of post-war Europe, including the German student circles which experienced Hunger nach Kultur ${ }^{44}$.

The Communists who had been banned in Finland in the 1930s now resurfaced and regrouped themselves. The intellectual Raoul Palmgren, former student activist of the radical social democratic student organization ASS (the Academic Socialist Society) who mostly had formulated the concepts of intelligentsia of the Left in the 1930s, became a major voice in defining the cultural policy of the Left. Palmgren also composed the culture policy programme for the newly founded Finnish People's Democratic League (SKDL) ${ }^{45}$, which was the first of its kind in Finland. In general, the leftist cultural views went through a formation period for some time after the war. They believed that culture should become the property of the people as a whole, and that artists should be supported financially by state grants and awards. A striking detail was the fact that Palmgren, whose essay anthology ${ }^{46}$ was referring to Snellman and other Fennomen thinkers, emphasised national culture while the Communist movement was otherwise striving to rid itself of the national characteristics. Despite the fact that he wanted the working class to lead the way culturally, Palmgren's thinking was nevertheless based on the bourgeois notion of cultural Finnishness which arose in the nineteenth century. His belief was, however, that the nationalism of the so-called "first republic" of Finland (1919-1944) had corrupted the cultural Finnishness. Indeed, this modernist

\footnotetext{
${ }^{44}$ Waldemar Krönig and Klaus-Dieter Müller, Nachkriegsemester. Studium in Kriegs- und Nachkrigzeit, 1990, quoted from Laura Kolbe, Sivistyneistön rooli. Helsingin yliopiston ylioppilaskunta 1944-1959, (Helsinki, 1993 ), 320.

${ }^{45}$ The Finnish People's Democratic League was a political organisation with the aim of uniting the Finnish Left outside the Finnish Social Democratic Party. The Finnish People's Democratic League used to be one of the largest leftist parties in Western Europe, with its main member party, the Communist Party of Finland, being one of the largest communist parties west of the Iron Curtain.

${ }^{46}$ Raoul Palmgren, Suuri linja. Arwidsonista vallankumouksellisiin sosialisteihin: kansallisia tutkielmia, (Helsinki, 1948).
} 
state-centred planning programme for science and culture became reality in the ensuing decades; in 1947, however, the traditionalist forces still prevailed. ${ }^{47}$

Palmgren as a "Finnish dissident" should be seen in the tradition of "Western Marxism" introduced by Perry Anderson ${ }^{48}$, namely because he focused on cultural phenomena and "superstructure" whilst the Finnish post-war communists emphasised economic and class struggle. Because of his views, Palmgren's political career ended in a split with the leadership of the Communist Party as early as $1952 .{ }^{49}$

In the late 1930s, academic L.A. Puntila, who belonged to the middle generation of the AKS, had already planned an extensive cultural/political programme, which he intended to be put into practice through the University of Helsinki. The plan moved ahead during the Second World War when Puntila, who served as the commander of the State Information Bureau during the war, was inspired by the culture of the front lines, where the soldiers dwelled in dugouts and were surrounded by entertainment. This experience strengthened his vision that cultural activities would flourish after the war and its fruits ought to be gathered in the spirit of Snellmanian national revitalisation. Naturally, students were best equipped for this task. The media was supposed to play a part in the process - the press, publishers, and radio. As such, the foundation of Puntila's vision was similar to Palmgren's: the educated classes, students, youth, and folk education inspired by the Fennoman movement.

\footnotetext{
${ }^{47}$ Allan Tiitta, Suomen Akatemian Historia I: 1948-1969. Huippuyksiköitä ja toimikuntia, (Helsinki, 2004), 56-7; Matti Rinne, Kiila 1936-2006. Taidetta ja taistelua (Helsinki, 2006), 162-4.

${ }^{48}$ Anderson, Perry, Considerations on Western Marxism (London 1976).

${ }^{49}$ Ilkka Liikanen, "Raoul Palmgren and the East and West of the Finnish Left" in Heidi Haggrén, Johanna RainioNiemi, Jussi Vauhkonen (eds.) Multi-layered Historicity of the Present. Approaches to social science history (Helsinki 2013), 61-74.
} 
Even though the statue of Snellman, the Fennoman movement's great man, was visited by the Academic Socialist Society of left-wing students in 1945, it was the vision of Puntila which emphasised the Snellman cult more in the spirit of the AKS. The aim of the AKS was to strengthen Greater Finland, both externally and internally. Now it was time to build a "Mentally Greater Finland." Puntila worried about the possibility of student youth falling under the influence of the People's Democrats to realise this vision. ${ }^{50}$

As in Finnish society in general, the leftists did not manage to gain power among the university intelligentsia after the post-war formation period. The post-war identity of Ylioppilaslehti, too, was still anti-communist, although it did not embrace any particular political views. Rather, it was balancing between different sides and avoided switching into any camps. Soon, the demands of "student as citizen" thinking were expressed as well. Academic Federation for Freedom (VAL), which in a way continued the anti-communist traditions of the AKS, specifically aimed to push Ylioppilaslehti in a more "ideological" direction. ${ }^{51}$ According to the VAL, culture signified "Finnish national culture," and Ylioppilaslehti was defending a "travesty of a student," who lived in an ideological vacuum: "living in an organized society entails that the members of society adapt to certain limits - individuality has its limits," as the secretary of VAL wrote in early 1952. This "warped individuality" presented itself, for example, in the idealization of "the ordinary student," from whom, in the spirit of the individualism advocated by Ylioppilaslehti, nothing could be demanded. ${ }^{52}$ The VAL insisted, however, that students were needed in particular among the elite, as the signpost that was formed by the educated classes.

\footnotetext{
${ }^{50}$ Kolbe, Sivistyneistön rooli, 314-16.

${ }^{51}$ The VAL was established in 1950, when it was possible to breathe more freely in Finland again. The nationalist motives of the organization included not only anti-communism but also aspirations to push the arts out of the way of politics in student activities.

52 Jussi Carpén, “Taistelu ylioppilaista”, Ylioppilaslehti 6/1952, 3; Kolbe, Sivistyneistön rooli, 366.
} 
It was evident that "individualists" referred to the new generation of modernist critics, whose important forum turned out to be Ylioppilaslehti in the 1950s ${ }^{53}$ On the whole, art criticism rose to prominence in the 1950s. The poems and essays of the modernist aesthetics reached beyond the socalled "birch bark culture" (ethnological national issues) of Finland, out into the international currents. All in all, there were plenty of different debating groups and literary circles formed after the war. The best known of these, the Eino Leino Society, was formed in 1947. It was named after the great Finnish poet and included most of the critics contributing to Ylioppilaslehti in the 1950s. After the left wing was no longer able to pose a threat to the cultural conservatives, a more comfortable juxtaposition developed between the independent liberal cultural intelligentsia and the conservatives.

Due to its pronounced cultural status, Ylioppilaslehti became an ever more significant actor within the Finnish cultural community in the 1950s, and, in the process, also generated increasing visibility for its ideas amongst the public at large. The cultural arena ranked high in the post-war hierarchy of Finland's public sphere. The cultural media, such as the cultural press, have been important public institutions. Nonetheless, cultural magazines have often been marginalised and acted as counter- or alternative public forums. The post-Second World War period was, however, exceptional in the sense that, during that time, a "professional journal" like Ylioppilaslehti, managed to have an impact on the entire public sphere at the national level. Of course, the paper has a relatively wide circulation for a cultural publication, reaching not only students, but also a wide readership outside of academia. ${ }^{54}$

\footnotetext{
${ }^{53}$ For more about Ylioppilaslehti and the Finnish public sphere of the 1950s, see Jukka Kortti, "Building the New Cultural Finland: the student magazine Ylioppilaslehti, the public sphere and the creation of the Finnish cultural elite in the post-war era", Scandinavian Journal of History, 36:4, (2011), 462-78.

${ }^{54}$ The circulation numbers of the paper doubled in the 1950 s, from approximately 10,000 to 20,000 . At the same time, the circulation of Finnish cultural periodicals peaked at a few thousand at the most. The circulation of Ylioppilaslehti expanded even faster in the next decade, with a circulation of 60,000 in 1970, which equalled that of national newspapers.
} 
But the young critics were by definition part of the historic legacy of the Finnish intelligentsia, where intellectuals, despite their ostensible radicalism, were close to the Snellmanian nation-state or at least did not work outside of it as in southern Europe, for instance. This group of young modernists, who later became the strong part of the national elite, certainly brought with their modernism something new for Snellmanian ideology by breaking down and rebuilding the national attributes. This was mainly done by restoring the idea of the fatherland and the language to the level of private experiencing. ${ }^{55}$ Snellman (and German idealism) was there as with the Young Finns in the early $20^{\text {th }}$ century, but more in terms of individuality. Besides poetry and literature, the same educational program was carried out by the film critics. Ylioppilaslehti had a central role in creating a new intellectual cinema culture, which involved essayistic literature on cinema and cinema club activities.

All in all, Ylioppilaslehti fits in with Habermas' concept of the normative public sphere, because it was about a deliberative and precisely bourgeois intelligentsia elite. Here it is also possible to discern similarities with Habermas's liberal model of democracy, as it reveals a preference for the liberties of private citizens. It must be stressed, however, that Habermas's notion is based above all on the tradition of political liberalism, whereas the Finnish modernists of the 1950s stressed their non-political nature. Indeed, for the most part, the modernism found in the pages of Ylioppilaslehti of the 1950s dealt with culture. Still, the Finnish modernists embodied the European post-war concept of an independent intellectual - although not as radical as Jean-Paul Sartre and others. However, the situation changed in the late 1950s. Now it was time for politics again. But in the context of the Cold War, the modernists did not rebel against the state, but started to line up behind Urho Kekkonen, the President of Finland.

\footnotetext{
55 Auli Viikari, "Ei kenenkään maa. 1950-luvun tropologiaa”, in A. Makkonen, ed., Avoin ja suljettu. Kirjoituksia 1950luvusta suomalaisessa kulttuurissa (Helsinki, 1992), 72-4.
} 


\section{THE RADICAL LEFT AND THE STATE}

In the 1960s, Ylioppilaslehti sympathised more and more with the Left, which was due to the changing demographics resulting from the flood of baby boomers into the universities. The expansion of educational opportunities made higher education more common in industrialised societies. The ideal of the normative public sphere that Ylioppilaslehti had followed so far was challenged by the increased internationality brought on by the media, and especially television. There were single-issue groups springing up, and the new left was raising its head. Modernity was on the move and the public sphere started turning towards what Chantal Mouffe ${ }^{56}$ calls "agonistic pluralism," which is more receptive than the deliberative democracy model to the multiplicity of voices that a pluralist society encompasses. It is worth bearing in mind, however, that this dialogue was, and still is, governed by the elite.

The movements of the sixties were antiauthoritarian. This was also the case in Finland if you look at the organizations the young Finnish intelligentsia established in the mid-1960s. Most of them, such as the pacifist peace organisation Sadankomitea (The Committee of One Hundred) relied on nonalignment thinking, albeit with close ties to the social democrats. Many of the activists studied social and political sciences, fashionable modernist disciplines of the 1960s, but also medicine. Before 1968, the Finnish student activism was mostly in the hands of liberal and left wing radicals. But when the Western New Left started to build a "collective intellectual" - a framework independent of party, state, and university ${ }^{57}$, the Finnish New Left took another direction. As in

\footnotetext{
${ }^{56}$ Chantal Mouffe, “Deliberative Democracy on agonistic pluralism?” Social Research 66 (3), Fall 1999, 745-59.

${ }^{57}$ Dick Flacks, "Making History and Making Theory. Notes on How Intellectuals Seek Relevance" in C. C. Lemert, ed., Intellectuals and Politics. Social Theory in a Changing World, 5 Key Issues in Sociological Theory, (Newbury Park, CA, 1991), 17.
} 
Finnish society in general during the extremely rapid modernization process of the sixties ${ }^{58}$, the student activists also had a strong belief in political parties, state politics, and the Scandinavian type of social welfare policy. Another Finnish peculiarity in the context of international student activism of the 1960s was the relation between the young intelligentsia and Finnish President Urho Kekkonen. Kekkonen, a former student radical, became "the Great Master" of the Finnish 1960s generation. While students in France and the U.S.A. bayed for their presidents to resign, the President of Finland invited young radicals to wine and dine at his residence (famous, so called “Children's Parties”). Kekkonen also supported the most visible and soon-to-become mythical Finnish action of 1968 - the occupation of the Old Student House in Helsinki. ${ }^{59}$

The Sixties was a "Revolution of the Intellectuals" as in 1848. It has been stated, that 1968 - "the year of the barricades" and "the year that rocked the world" 60 - was particularly a matter of the collision of traditions and institutions. The old world, Bourgeoisie hegemony, a fashionable term in 1968, was challenged. Both sociologists and left-wing youth politicians used the term. The entire decade of the 1960s was "the great age of Theory" as Tony Judt puts it. The Western new Left exhumed the writings of Rosa Luxemburg, Georg Lukacs, Antonio Gramsci, and other forgotten early-twentieth century Marxists, who were accompanied by the rediscovery of Marx himself. ${ }^{61}$

But unlike in other Western countries, the Finnish intelligentsia for the most part chose the "old" Marx of Lenin after 1968: authorized democratic centralism and proletarian dictatorship. And the master was particularly Lenin, not Trotsky or Mao, as in most other radical movements in the West during the time. So-called Taistoism was a Finnish version of the Stalinistic, orthodox communist

\footnotetext{
${ }^{58}$ Finland's economic growth in the postwar period was extraordinary. The average annual rate of real national product growth by country was 5 percent in Finland in the 1960s and, for instance, about 3.3 percent in Sweden, Denmark and Norway during the same period.

${ }^{59}$ About the year 1968 in Finland, see Laura Kolbe "From Memory to History: Year 1968 in Finland" Scandinavian Journal of History 4/2008, 366-81.

${ }^{60}$ David Caute, Sixty-Eight: The Year of the Barricades, (London, 1988); Kurlansky, 1968.

${ }^{61}$ Tony Judt, Postwar. A History of Europe Since 1945 (New York, 2005), 398, 403, 407.
} 
movement in the 1970s, which started to take shape after the Soviet Union occupation of Czechoslovakia in August 1968. This was a turning point, after the radical left turned pro-Soviet. Another remarkable feature compared to other Western extreme left wing movements of the time, was that Taistoists joined the political party (The Communist Party of Finland SKP) right from the beginning. Although the Taistoists never had a majority anywhere - not even in SKP in which more of a Euro-communist faction had a majority - they had an influence on the Finnish public sphere, since they were a small but vocal minority among the cultural and academic elite, and they had a powerful ally, the Soviet Union, who had a habit of getting involved in Finnish internal affairs. Why the most progressive faction of the Finnish academic youth turned to the Leninist student movement in the 1970s is a major (and still comprehensively unstudied) phenomenon in the history of Finland. ${ }^{62}$ This is, however, not the proper forum for analysing the topic thoroughly either, but in the context of the history of the Finnish intelligentsia, the activism of this movement is interesting.

AKS can be seen as a predecessor of the Taistoists, although the former comes from the extreme right and the latter from the extreme left. Besides- the fact that both movements arose from the deteriorating expectations for the academics in the future (the weakening of social positions, jobs and salaries) they both leaned on the "people" that they considered the hard-working core of society. AKS nationalists identified, in the context of the Fennoman movement, with the traditional peasantry, whereas Leninists gravitated to the ranks of the working class. ${ }^{63}$ According to social scientist Matti Virtanen, who had studied Finnish societal generations, the new left movement and its radicalisation went through different phases, but actually originated from within the Fennoman movement, although it was actualised differently. On the other hand, the historian of the Student

\footnotetext{
${ }^{62}$ About the ideological themes of the movement and the reasons behind the drastic turn, see Jukka Relander, "From Flowers To Steel. Development of the Leninist Mind in Finland 1968-1972”, Scandinavian Journal of History, 33(4) 2008, 464-477.

${ }^{63}$ Jukka Relander, "From Flowers to Steel. Development of the Leninist Mind in Finland 1968-1972" Scandinavian Journal of History 4/2008, 467.
} 
Union of the University of Helsinki Laura Kolbe emphasises that 1968 represented first and foremost the break with a long patriotic tradition. ${ }^{64}$

It is true that the same Snellman can be found in the writings of the academic Leninists. They adopted the original Western Humboldtian ideals ${ }^{65}$ of higher education. ${ }^{66}$ This was expressed in the 1970 pamphlet Johdatus uuteen yliopistoon ${ }^{67}$ (Introduction to the New University). The pamphlet was linked to the university administrative reform of the time and demanded democratic, free Humboldtian University ideals instead of the technocratic monopoly and capitalistic politics of higher learning: Bildung durch Wissenschaft. The most interesting article in the pamphlet is that by Kari Toikka, in which he connects the Leftist lines and Snellmanian university ideals: the unity of science, research and teaching, and the freedom of teaching and studying: "The division of defenders and demoralisers of the university as a consequence of ahistorical definitions of university circumstances is ideological and false - especially when professors and students are pitted against each other as different groups." ${ }^{\circ 8}$ Toikka later noted that through Snellman, they easily got their hands on the classical university idea. He thought that it was "a funny accident" that Snellman spoke very simply about the same ideas they had, and the topic was linked to the Finnish university tradition. ${ }^{69}$ In addition, the academic Taoistoists rediscovered the essays by Raoul Palmgren from the 1940s in the 1970s.

Although President Kekkonen began to keep the radical left at arm's length in the 1970s, the radicals and Kekkonen shared a common enemy — old school conservative patriots in the

\footnotetext{
${ }^{64}$ Matti Virtanen, Fennomanian perilliset: poliittiset traditiot ja sukupolvien dynamiikka (Helsinki, 2001), 380-381; Laura Kolbe, Eliitti, traditio ja murros. Helsingin yliopiston ylioppilaskunta 1960-1990 (Helsinki, 1996), 10-11.

${ }^{65}$ E.g. Sylvia Paletschek, "DieErfindung der Humboldtschen Universität. Die Konstruktion der deutschen Universitätsidee in der erste Hälfte des 20. Jahrhunderts," Historische Anthropologie 10(2002), 183-205.

${ }^{66}$ Kolbe, "From Memory to History", 375.

${ }^{67}$ Pekka Aarnio and Mikael Böök and Antti Kasvio and Kari Toikka and Matti Viikari, Johdatus uuteen yliopistoon (Helsinki, 1970).

${ }^{68}$ Kari Toikka "Akateeminen kasvastus ja akateeminen vapaus" in P. Aarnio and M. Böök \& A. Kasvio \& K. Toikka \& M. Viikari, Johdatus uuteen yliopistoon (Helsinki, 1970), 133.

${ }^{69}$ Veikko Koivusalo and Timo Kallinen, ed., Pitkä 70-luku. Valokuvia ja muistikuvia (Helsinki, 2000), 177.
} 
university, but also in foreign politics. The relations between Finland and the Soviet Union were crucial for Finland in many ways; not just in foreign politics, but also in economic, domestic, and cultural policy. The early 1970s in particular were difficult times for these relations, and Kekkonen did everything necessary to weaken the influence of conservative dissenters. On the other hand, the Taistoists were the first ones to contribute to the political "peace and friendship" between the Soviet Union and Finland, which was called Finlandizierung ${ }^{70}$ (Finlandisation). However, cringing and toadying to Russians consumed the entire Finnish political sphere in the 1970s, excluding minority right wing and populist factions. As in the policies of Fennomen in the era of the Grand Duchy in the nineteenth century, the relations with the eastern power were important. All in all, the principal themes of the Fennoman movement can be found in the activities of Taistoists: loyalty to Russians, the strong state, and the importance of education. Although the frame of reference for "the people" was different, Snellman was still there.

\section{CONCLUSION: INTELLIGENTSIA, THE (WELFARE) STATE, AND POSTMODERN}

\section{CHALLENGES}

Although we would strictly consider intellectuals to be individuals apart from the dominant culture, the place of the intellectual in the society can be neither inherently contradictory nor abusive. His or her role lies in the capacity to assume responsibility and move away from interpreting the society from a particular ideological dogma. And this is particularly true for the new nations. ${ }^{71}$ But Finland can be seen as a special case even in this context. The national vocation has fettered public debate in Finland: the contribution of the academic elite to nation-making was, in Finland, even more

\footnotetext{
${ }^{70}$ The term, still controversial among the Finnish historians, was used to describe the influence of a powerful country on the policies of a smaller neighbouring country. It is originated in West German political debate, chiefly by Franz Josef Strauss, in the late 1960s and 1970s. See e.g. David Kirby, A Concice History of Finland. (Cambridge, 2006), 245-246, 267.

${ }^{71}$ Lipset \& Basu, "The Intelligentsia and the Intellectuals", 144.
} 
significant than in Europe's other new nations, and the professors were subject first and foremost to the state. ${ }^{72}$

Now the crucial question arises: is this a problem? What harm could the close link between intellectuals and the state do to a country? One could claim that the strong state has colonized the civil society. This argument refers to the fact that Nordic countries in general have been seen as corporatist societies and therefore, at least from an Anglo-American view, could be seen as promoting a narrowing of the liberal civil society. But as German historian Norbert Götz ${ }^{73}$ has pointed out, the matter of civic involvement in state affairs has been just as important as the question of the state's autonomy. The relationship between the state and civil society is not simply contradictory, and we must take into consideration the complex intellectual and political traditions of the Nordic countries. One important factor in Nordic history is the relatively strong tradition of the so-called popular movements (Protestant revivalists, the temperance movement, the agricultural movement, and the labour movement, as well as sports, language, and women's organizations) with their associations which could be seen as part of the civil society.

Social movements are places where legitimate intellectual labourers can seek and gain recognition in new arenas. They are also places where intellectuals can be made. ${ }^{74}$ The movements have been relatively autonomous in the Nordic countries. However, this does not actually apply to Finland, which has experienced a marked tradition of state control over civil society by the detailed Finnish Law on Associations that requires official registration. Although student activism as the genesis of "movement intellectuals," especially in the 1960s, has often been seen as an attempt to question the

\footnotetext{
${ }^{72}$ Klaus Mäkelä: 'Kansallinen kutsumus on kahlinnut kansalaiskeskustelua' Helsingin Sanomat, December 24, 1988 quoted from Katarina Eskola "Women and the Media-related Intellectual Public Sphere", in Niilo Kauppi \& Pekka Sulkunen (eds.) Vanguard of Modernity. Society, Intellectuals, and the University,Publications of the research unit for contemporary culture 32, Jyväskylä: University of Jyväskylä, 150.

${ }^{73}$ Norbert Götz, "Century of Corporatism of Century of Civil Society? The Northern European Experience", in Norbert Götz \& Jörg Hackmann (eds.) Civil Society in the Baltic Sea Region. (Hampshire \& Burlington, 2003), 37-48.

${ }^{74}$ Eyerman, Between Culture and Politics, 11.
} 
power structures, the link between the Finnish student elite and the state has also remained strong in the latter part of the $20^{\text {th }}$ century.

In the Finnish case, Götz ${ }^{75}$ refers to the fact that the establishment of stable corporatist structures in the labour market did not succeed before the late 1960s. For me, the historical background for this Finnish peculiarity in the Nordic context, which could be seen as problematic against the idea of civil society, is the legacy of the bloody Finnish Civil War and the geopolitical situation of Finland.

However, the histories of Nordic welfare states include three different ideological elements: the idealised heritage of the free independent peasants, the spirit of capitalism, and the utopia of socialism. To achieve this goal of the welfare state, the process has demanded not only statecentrism but wide consensus, involving collective agreements among different political parties. ${ }^{76}$ Although the process was extraordinarily rapid from the 1960s to the 1980s, Finland was a latecomer among Nordic countries in building its welfare state, yet one can still find all the ideologies within the intellectual activism discussed above. The "Nordic corporatist model" has meant the building of welfare states with certain social policies (public social services, etc.) but it has also affected all institutions, including media ${ }^{77}$ - and universities.

Besides the Nordic context, Finnish intellectual history - in fact all history - must be seen in relation to Russia, and later, the Soviet Union. As the Finnish history sociologist Risto Alapuro ${ }^{78}$ has stated, the Finnish intelligentsia has lived "in the shadow of Russia." Most of the time it has meant that the "state intellectuals" have been forced to cope with the neighbouring super power.

\footnotetext{
${ }^{75}$ Götz, "Century of Corporatism of Century of Civil Society?", 45.

${ }^{76}$ Pauli Kettunen, "The Tension between the Social and the Economic - A Historical Perspective of a Welfare State" in Jari Ojala \& Jari Eloranta \& Jukka Jalava, The Road to Prosperity. An Economic Hiastory of Finland (Helsinki, 2006) 285-313.

${ }^{77}$ About the "Democratic Corporatist Model" in Media Systems see Daniel C. Hallin \& Paolo Mancini, Comparing Media Systems. Three Models of Media and Politics (Cambridge, 2004), 73-75.

${ }^{78}$ Alapuro, Suomen älymystö Venäjän varjossa.
} 
There are periods when the Finnish intelligentsia have had an opportunity to question the Russian rule during its turmoil on one hand, as well as to blindly obey its politics on the other. Nevertheless, they have never really given up the Snellmanian ideas of the State and Bildung.

Then, according to Snellmanian thinking, should we talk about the "educated class" (in Finnish sivistyneistö, in German Bildungsbürgertum, and in French classe cultivée) rather than “intellectuals" or "intelligentsia?" Although many languages make a distinction between the two, they are often mixed. It is obvious that habitually what we call intellectuals are actually "intellectual labour," although intellectuals are not a class in the economic sense, but a social category, or perhaps a social stratum.

East-German poet and author Rainer Kirsch expressed to a Finnish journalist recently, that "intellectual" was a curse word in the DDR. ${ }^{79}$ In a way, the same situation has existed in Finland since the 1970s, when the Finnish intelligentsia started to lose its significance. When the national public sphere meant first and foremost the bourgeois public sphere (Bürgerliche Öffentlichkeit) for the radical left, the large group of Finnish intelligentsia retreated to write to each other in their own community. That is why none of the young intellectuals could achieve the independent role of a "public" intellectual. ${ }^{80}$ There are two historical paradoxes in this development. When the left finally occupied the Finnish intelligentsia, its importance diminished. On the other hand, when the Finnish political atmosphere started to be released from the "Finlandisation" in the post-Kekkonen era in the 1980s, the new times questioned the whole idea of an intellectual.

It is not a coincidence that this development is parallel to the importance of Ylioppilaslehti in the Finnish public sphere. In the 1980s, the essentials for the existence of the intelligentsia had changed

\footnotetext{
${ }^{79}$ Radio programme "Berliini - taiteilijakuvia jaetusta kaupungista", part 1, Historiasarjoja. YLE Radio 1. Jenni Stammeier. September 29, 2010.

${ }^{80}$ Matti Hyvärinen, Viimeiset taistot. Taistolainen opiskelijaliike, kertomus ja retoriikka (Tampere, 1994$), 333$.
} 
along with the institutionalisation of the university system and changes in media. The rising of postmodernism impugned and even ridiculed the whole idea of a Finnish intellectual. For intellectuals of postmodern times, it has been typical that they readily present categorical truths about the diminishing significance of the intelligentsia, and thereby undermine the validity of their own argument ${ }^{81}$.

This became evident in 1989, for instance, when Finnish sociologists organized an inquiry in collaboration with cultural editors of the leading Finnish newspaper Helsingin Sanomat about who is who in the Finnish intelligentsia. The original idea and pattern for the research came from the French review Lire from 1981 and French sociologist Pierre Bourdius's critique of it. One of the findings of the research was that a typical Finnish intellectual is employed by the state (including the university) or financed by a government grant. As the sociologists who conducted the research noted:

The specific feature of Finnish intellectual has, for historical reasons, been their dependency on the state. The connection between the university and politics has been very close. Now this connection has become less thin, but especially between academic intellectuals and the state, the connection is still a close one. ${ }^{82}$

In fact, the critique by Erno Paasilinna mentioned in the introduction was based on these inquiry results. It seems that this strong link between the intelligentsia and the state in Finland makes the idea of a Finnish intellectual an easy target, not only for ironic and sarcastic columnists, but for the "common people" as well. The latest debate on the topic, with statements such as "there are no real intellectuals in Finland" occurred in the Finnish public sphere when the former Prime Minister

\footnotetext{
${ }^{81}$ See Pasi Saukkonen, Pasi "Intellekuaalinen rooli ja kansallinen identiteetti", in Pertti Karkama \& Hanne Koivisto, eds., Älymystön jäljillä. Kirjoituksia suomalaisesta sivistyneistöstä ja älymystöstä. Tietolipas 151, (Helsinki, 1997), 332-47.

${ }^{82}$ Keijo Rahkonen and J. P. Roos, 'The Field of Intellectuals: The Case of Finland', in Kauppi \& Pekka Sulkunen (eds.) Vanguard of Modernity. Society, Intellectuals, and the University, Publications of the research unit for contemporary culture 32 (University of Jyväskylä, 1992), 122.
} 
Paavo Lipponen listed the Finnish intellectuals in his book on Bildung published in $2008^{83}$. The debate triggered several sarcastic comments. Again, it was not easy to be a Finnish intellectual because your existence was questioned.

Another, more universal threat to the intellectual culture is the rise of technocracy, which is embedded in the current international university reforms. There are signs recalling the post-Second World War controversy of "the two cultures." 84 The conflict between humanities and "hard sciences" seems to rear its head during the university reforms. When the long running Finnish degree reform ${ }^{85}$ - including the American-style system of measuring studies in credit points finally came to an end in the early 1980s, the university historian and humanist Matti Klinge ${ }^{86}$ emphasised that the society should understand the disadvantages of educating students only to a job: "If we will have an uncritical intelligentsia around the year 2000, the democracy is in danger." Despite a few Finnish intellectual dissidents, the vision has come true in the 2000s, although, looking back on the history of the Finnish intelligentsia, there has never really been an intellectual stratum opposed to the state. However, if universities are seen only in terms of efficiency, commerce, and (technological) innovation, the critical intelligentsia is in danger of becoming extinct — not only in Finland, but in all of the Western world.

\footnotetext{
${ }^{83}$ Paavo Lipponen, Järki voittaa. Suomalainen identiteetti globalisaation aikakaudella (Helsinki, 2008).

${ }^{84}$ The most famous example of the dispute is from the early 1960s, when the British intellectuals; scientist-turnednovelist C.P. Snow and literary critic F.R. Leavis had a public intellectual conflict between competing visions of Britain's past, present, and future (see e.g. Guy Ortolano, The Two Cultures Contorversy. Science, Literature and Cultural Politics in Postwar Britain (Campbridge, 2009). However, the dispute between arts and sciences could be found in other parts of post war Europe as well, such as Finland in the 1950s.

${ }^{85}$ The degree reform was a part of the emergence of modern Western science policy created in the late 1950s and the early 1960s. A "system of higher education" paralleled a new conception of science as a productive power, contributing to economic growth as well as to the knowledge base. This conception was closely related to the heightened importance of applied science and technology as a means of boosting productivity and competitiveness in the world shadowed by the Cold War. (Marja Jalava, "Cultural Revolution or Bureaucratic Jargon: The Finnish Degree Reform of the 1970s", A paper presented at the European Social Science History Conference ESSHC 2008.)

${ }^{86}$ Kimmo Henriksson, "Professori Matti Klinge: Kurssimainen opiskelu näivettää" Helsingin Sanomat 13.2.1983.
} 